\title{
Editorial:
}

\section{Fundamental Guideline for Writing an Academic Research Proposal and Some Common Mistakes}

\section{*Samia A $\mathbf{A}^{\mathbf{1}}$, Saiful $\mathbf{A}^{\mathbf{2}}$}

1. Senior Lecturer, Dept. of Public health, Lincoln University College, Malaysia.2. Post graduate Master student, Dept. of Business management, SEGi University, Malaysia.

Article info: Received: November 05, 2016, Accepted: November 26, 2016

\section{Abstract}

A research proposal is an essential scheme of any research. The contentment of any research is relying on the outstanding quality of research proposal. Both the social and health science research proposal writing depends on numerous factors which may be quality benchmarks, budget, time frame and many more. A research proposal should provide an outline of research which helps a reader to understand the scope and value of research work. So, the aim of this article is to provide a brief fundamental ideas and guild lines for a new researcher as well as students.

Keywords: Writing, Research, Proposal, Common mistake

\section{Introduction}

Research is a scientific and systematic investigation to collect new knowledge, information, and appropriate solution of a problem to establish a fact and reach a new conclusion. It is a critical investigation through which the area of knowledge will expand. So, before conduct a research, a researcher should prepare a proposal which will be a blueprint for the proposed research ${ }^{1}$. Writing a research proposal is a vital step within the research process.

\section{*Address of correspondence:}

Dr. Samia Amin

Senior lecturer

Dept of Public health, Lincoln University

College , Kelana Jaya, Post code: 47301

Selangor, Malaysia.

Telephone: +60142996859

Email: drsamia27@gmail.com
There are no specific format for writing a proposal for research, it depends on type of research, institutions, or funding companies.

If the proposal is writing for academic purpose like thesis or dissertation, then the supervisor can recommend their own point of interest ${ }^{2}$. So, there are numerous steps to be undertaken by researcher to prepare a quality research proposal. The purpose of the research proposal is to show the strategic ideas of the research question and significance of the problem statement to the supervisory committee, ethics clearance board as well as the funding agency.

\section{Basic Component of Research Proposal:}

Research proposal is a key that unlocks the door to the research endeavor. A research proposal needs to contain all the key elements in research and sufficient information ${ }^{3}$. So it is very crucial for a researcher to write a coherent, clean and compelling research proposal in a structured format. 
A vague, susceptible or incomplete research proposal can cause a delayed and unsuccessful research implementation. A good and well thought research proposal must have some basic components that shows in Figure1.

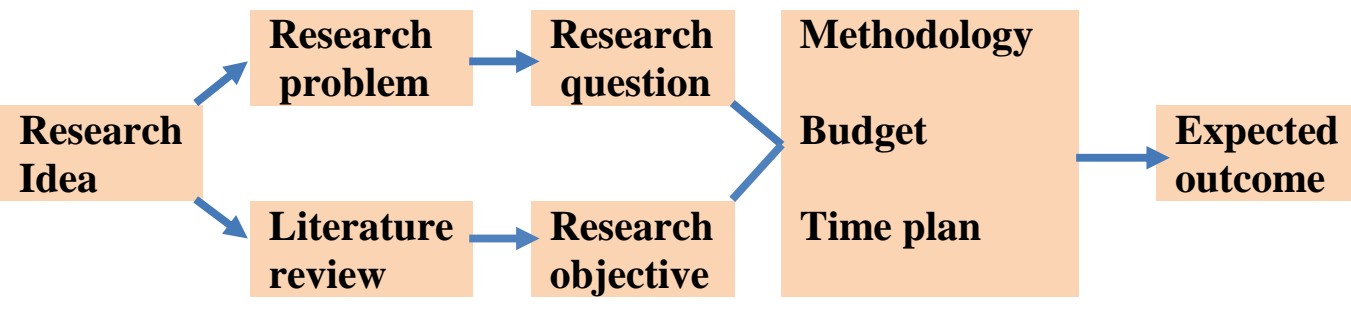

\section{Research Proposal Outline}

There are no tough rules governing the structure or component of a proposal ${ }^{4}$. It mostly depends on the type of study design; as well formal approval by a particular university or sponsoring agency. Table 1 frame the outline of a typical format of research proposal:

\begin{tabular}{|c|c|c|}
\hline \multicolumn{3}{|c|}{ Table 1: Research Proposal Outline } \\
\hline CHAPTER & COMPONENT & KEY POINTS \\
\hline \multirow[t]{2}{*}{ Cover page } & $\begin{array}{l}\text { - Topic/Title } \\
\text { - Name of researcher } \\
\text { and co researchers } \\
\text { - Institution }\end{array}$ & $\begin{array}{l}\text { Title should be descriptive of focus, simple, concise, eye-catching } \\
\text { and use key words. } \\
\text { Example: Effectiveness of educational intervention on stage of } \\
\text { change in smoking cessation among the undergraduate university } \\
\text { students. }\end{array}$ \\
\hline & Table of contents & $\begin{array}{l}\text { - Uses a hierarchy for heading and sub-heading } \\
\text { - Page number should be given sequentially }\end{array}$ \\
\hline Abstract & $\begin{array}{l}\text { - Background } \\
\text { - Methodology } \\
\text { - Expected outcome } \\
\text { - keywords }\end{array}$ & $\begin{array}{l}\text { It starts by describing the background, then state the methodology and } \\
\text { finally concludes the expected outcome with anticipated implications; } \\
\text { should be written last approximately } 250-300 \text { words, as a concise } \\
\text { summary of the proposal. }\end{array}$ \\
\hline \multirow[t]{6}{*}{ Chapter 1} & Introduction & $\begin{array}{l}\text { The introduction typically begins with a general statement of the } \\
\text { problem area with logical information }\end{array}$ \\
\hline & Background & $\begin{array}{l}\text { - Establish the context of the research problem } \\
\text { - Helps the reader to get a preliminary understanding of the } \\
\text { problem }\end{array}$ \\
\hline & Research problem & $\begin{array}{l}\text { - A good statement of problem clearly defines the problem. } \\
\text { - The problem statements will lead to a research questions }\end{array}$ \\
\hline & Significance & $\begin{array}{l}\text { Explain } \\
\text { - } \quad \text { potential value of the study } \\
\text { - } \quad \text { add scholarly knowledge } \\
\text { - } \quad \text { practical implication } \\
\text { - } \quad \text { how it will improve policy } \\
\text { - } \quad \text { new program planning } \\
\end{array}$ \\
\hline & Research question & $\begin{array}{l}\text { It should be clear, focused, arguable, relevant, consistent and } \\
\text { interesting } \\
\text { Example: Role of diet on student performance } \\
\text { Research question: What is the relationship between the diet and } \\
\text { student performance in class? }\end{array}$ \\
\hline & Research hypothesis & $\begin{array}{l}\text { - Hypothesis are generated from specific theories } \\
\text { - Hypothesis is the best guess by researcher to answer research }\end{array}$ \\
\hline
\end{tabular}




\begin{tabular}{|c|c|c|}
\hline & & $\begin{array}{l}\text { question } \\
\text { - Research question: what is the relationship between physical } \\
\text { activity and anxiety among working women? } \\
\text { Hypothesis: Physical activity reduce anxiety among working women }\end{array}$ \\
\hline & Research objectives & $\begin{array}{l}\text { The component of the objective should be SMART } \\
\text { - } \text { Specific } \\
\text { - Measurable } \\
\text { - } \text { Achievable } \\
\text { - } \text { Realistic } \\
\text { - } \text { Time-bound }\end{array}$ \\
\hline & Operational definition & $\begin{array}{l}\text { Operational definitions are precisely define which will be } \\
\text { commonly use in the research proposal. }\end{array}$ \\
\hline & Limitation & $\begin{array}{l}\text { Two types of study limitation; } \\
\text { i. Design limitation } \\
\text { ii. Researcher limitation } \\
\text { - Research design is largely established by the limitations of the } \\
\text { researcher. } \\
\text { Time should be consider to complete the study, budget constraints, } \\
\text { and physical proximity. }\end{array}$ \\
\hline \multirow[t]{2}{*}{ Chapter 2} & Literature review & $\begin{array}{l}\text { The key objective of the literature review is to demonstrate that the } \\
\text { proposed research will fill an important gap in the current research. } \\
\text { So, } \\
\text { - It provide comprehensive review and references } \\
\text { - It should discuss relevant study } \\
\text { - It is very selective and critical } \\
\text { - Needs to be up to date } 5-10 \text { years before relevant research with } \\
\text { - } \quad \text { Proper referencing } \\
\text { - Devides new theoretical insights }\end{array}$ \\
\hline & $\begin{array}{l}\text { Conceptual } \\
\text { framework }\end{array}$ & $\begin{array}{l}\text { Presented by any of the following } \\
\text { - } \quad \text { Flow charts } \\
\text { - Tree diagrams. } \\
\text { - } \quad \text { Shape based diagrams - triangles, concentric circles, } \\
\text { overlapping circles. } \\
\text { - Mind maps } \\
\text { - } \quad \text { Soft systems }\end{array}$ \\
\hline \multirow[t]{2}{*}{ Chapter 3} & $\begin{array}{l}\text { Research } \\
\text { methodology }\end{array}$ & $\begin{array}{l}\text { - Study location } \\
\text { - Study design } \\
\text { - Sampling population } \\
\text { - Sampling frame } \\
\text { - Inclusion and exclusion criteria } \\
\text { - Sampling unit } \\
\text { - Sample size estimation } \\
\text { - Sampling method } \\
\text { - Study variables } \\
\text { - Instrument and data collection technique } \\
\text { - Instrument } \\
\text { - Validity and Reliability } \\
\text { - Data analysis }\end{array}$ \\
\hline & Expected outcome & $\begin{array}{l}\text { The expected result should answering the research questions and } \\
\text { research objectives; and back up with statistics and theory employs in } \\
\text { the study. }\end{array}$ \\
\hline
\end{tabular}




\begin{tabular}{|l|l|l|}
\hline Ethics & $\begin{array}{l}\text { - Inform consent form } \\
\text { - Patient information } \\
\text { sheet }\end{array}$ & $\begin{array}{l}\text { All ethical requirements of institution or research including consent } \\
\text { should be indicated. }\end{array}$ \\
\hline Work plan & $\begin{array}{l}\text { - Gantt's chart } \\
\text { - Time line } \\
\text { - Flow chart }\end{array}$ & It present the timeline of various activities that researcher plan. \\
\hline Budget & $\begin{array}{l}\text { Different funding } \\
\text { agencies have } \\
\text { different format and } \\
\text { requirement for } \\
\text { research budget } \\
\text { preparation. }\end{array}$ & $\begin{array}{l}\text { Preparing a detailed budget during the proposal stage can minimize } \\
\text { budget management difficulties during project implementation once } \\
\text { the project is funded. }\end{array}$ \\
\hline $\begin{array}{l}\text { Different source } \\
\text { - Article } \\
\text { - Books } \\
\text { - Website } \\
\text { - Newspaper } \\
\text { - Conference } \\
\text { proceedings } \\
\text { Different style }\end{array}$ & $\begin{array}{l}\text { - APA style } \\
\text { - Vancouver } \\
\text { - Harvard style }\end{array}$ & - May use soft wares such as Endnote or Refworks to help in writing \\
\hline
\end{tabular}

\section{COMMON MISTAKES IN WRITING PROPOSAL}

To write a best quality research proposal the researcher should adhere to guidelines required by the institution, organization, or funding agency to which the proposal will submit ${ }^{4}$. In writing the first draft of proposal, the researcher should focus more on organization and logical thought sequences than on exact wording, grammatical correctness and spelling. Assume that the readers know nothing about the proposed proposal; so describe the proposed methodology with as much detail and precision as possible. Although researcher take full concern in writing the proposal but still there are some common mistakes happen which is highlighted in Table 2

\begin{tabular}{|c|c|}
\hline \multicolumn{2}{|c|}{ Table 2 : Common mistakes in writing proposal } \\
\hline $\begin{array}{l}\text { Mistakes related to the research } \\
\text { problem }\end{array}$ & $\begin{array}{l}\text { - Unclear purpose of the research } \\
\text { - Unimportant problem } \\
\text { - Poorly supported hypothesis } \\
\text { - Problem is too complex } \\
\text { - Problem has limited relevance to the field }\end{array}$ \\
\hline $\begin{array}{l}\text { Mistakes related to the research } \\
\text { design \& methodology }\end{array}$ & $\begin{array}{l}\text { - Vague and unfocused description of design and method } \\
\text { - Data inappropriate for the research problem } \\
\text { - Methodology/procedures inappropriate for the research problem } \\
\text { - Appropriate controls lacking or inadequate } \\
\text { - Outdated or inappropriate equipment } \\
\text { - Poorly considered statistical analysis }\end{array}$ \\
\hline Mistakes related to the investigator & $\begin{array}{l}\text { - Insufficient training or experience for the proposed research } \\
\text { - Unfamiliar with the literature relevant for the proposed research } \\
\text { - Insufficient time to devote to the project }\end{array}$ \\
\hline Mistakes related to resources & $\begin{array}{l}\text { - Institutional setting is unfavorable for the proposed research } \\
\text { - Proposed use of equipment, support staff, or other resources is } \\
\text { unrealistic. }\end{array}$ \\
\hline
\end{tabular}




\section{Conclusion}

An accurate and significantly designed proposal can overcome the common pitfalls that give credibility statement concerning the investigator.

\section{References:}

1. Al-Riyami, A. (2008). How to prepare a Research Proposal. Oman Medical Journal, 23(2), 66-69.

2. Abramson, J.H. \& Abramson, Z.H. (2004). Survey Methods in Community Medicine: Epidemiological Research, Programme Evaluation and Clinical Trials. Fifth Edition. Churchill Livingstone: London.

3. Gerard M. Crawley and Eoin O'Sullivan (2015), The Grant Writer's Handbook: How to Write a Research Proposal and Succeed, Imperial college press, London

4. Paul D.L. \& Jeanne E.O. (2016), Practical Research: Planning and Design. $11^{\text {th }}$ Edition. Pearson Education limited: USA 